\title{
Synthesis, crystal structure and magnetic properties of bis $(1,1,1,5,5,5$-hexafluoropentane- 2,4-dionato) manganese(II) complexes with diazine ligands
}

\author{
Dang-Ming Hong ${ }^{\mathrm{a}}$, Ho-Hsiang Wei ${ }^{\mathrm{b} *}$, Kuo-Hui Chang ${ }^{\mathrm{b}}$, Gene-Hsiang Lee ${ }^{\mathrm{c}}$ \\ and $\mathrm{Yu} \mathrm{Wang}{ }^{\mathrm{c}}$
}

${ }^{a}$ Tzu-Chi Junior College of Nursing, Hualien, Taiwan

${ }^{b}$ Department of Chemistry, Tamakng University, Tamsui, Taiwan

${ }^{\mathrm{b}}$ Instrumental Center of College of Science, National Taiwan University, Taipei, Taiwan

(Received 8 December 1997; accepted 14 April 1998)

\begin{abstract}
One dinuclear $\left[\mathrm{Mn}_{2}(\mathrm{hfac})_{4}(\mu\right.$-pyz $\left.)\left(\mathrm{H}_{2} \mathrm{O}\right)_{2}\right] 2 \mathrm{H}_{2} \mathrm{O}(\mathbf{1})$ and three mononuclear complexes $\left[\mathrm{Mn}(\mathrm{hfac})_{2}\right.$ $($ pym $\left.)\left(\mathrm{H}_{2} \mathrm{O}\right)\right](2),\left[\mathrm{Mn}(\mathrm{hfac})_{2}(\mathrm{pydz})_{2}\right](3)$, and $\left[\mathrm{Mn}(\mathrm{hfac})_{2}(\mathrm{mpydz})_{2}\right](4)(\mathrm{Hhfac}=1,1,1,5,5,5$-hexafluoropentane2,4-dione, $p y z=$ pyrazine, $p y m=$ pyrimidine, $p y d z=$ pyridazine, and $m p y d z=3$-methylpyridazine $)$ have been synthesized and their crystal structures and cryomagnetic properties have been investigated. Complex 1 has a centrosymmetric dinuclear structure with two adjacent manganese atoms linked by a pyz ligand. The geometry about each manganese atom is distorted octahedral with $\mathrm{NO}_{5}$ coordination sphere. The structure of complex 2 is a mononuclear manganese complex with a distorted octahedral geometry of $\mathrm{NO}_{5}$ coordination sphere. The crystal structures of complexes 3 and $\mathbf{4}$ consist of mononuclear manganese complex with the $c i s-\mathrm{N}_{2} \mathrm{O}_{4}$ sixcoordination sphere. The temperature dependence of magnetic data for $\mathbf{1}$ revealed a dinuclear spin $\left(S_{1}=S_{2}=5 / 2\right)$ weak antiferromagnetic exchange interaction with $J=-0.47 \mathrm{~cm}^{-1}$. Complexes $2-4$ play a cryomagnetic behaviour followed the Curie-Weiss law. (C) 1998 Elsevier Science Ltd. All rights reserved
\end{abstract}

Keywords: crystal structure; magnetic properties; manganese complexes; binuclear complexes; diazine complexes.

\section{INTRODUCTION}

The coordination chemistry of manganese has achieved remarkable progress in the past decade due to the increased recognition of this metal's role in the biological system involved in the oxygen-evolving complexes of photosystem II of green plants $[1,2]$ and catalases $[1,3,4]$.

A number of manganese-containing, non-haem catalases have, in recent years, been isolated and characterized [3, 4]. This important class of metalloprotein catalyses the disproportionation of hydrogen peroxide to dioxygen and water very efficiently. Recently, some studies have been achieved in the preparation of a

\footnotetext{
* Author to whom correspondence should be addressed.
}

number of functional, non-haem catalase mimics of the model manganese complexes $[5,6]$.

As part of our continuing studies into the magnetostructural correlation of manganese(II) complexes with 2,2'-dipyrimidine (bpym) [7], very recently, we have prepared three complexes of bis(2,4-pentanedionate)manganese(II) with diazine ligands and these complexes exhibited high catalytic activity for $\mathrm{H}_{2} \mathrm{O}_{2}$ disproportionation [8]. Heterocyclic diazines, such as pyrazine, pyrimidine and pyridazine, are known to be an excellent bidentate ligand when coordinated to metal ions [9]. In our laboratory, we have continually prepared four new bis(1,1,1,5,5,5-hexafluoropentane-2,4-dionate)manganese(II) complexes with diazines: $\left[\mathrm{Mn}_{2}(\mathrm{hfac})_{4}(\mu\right.$-pyz $\left.)\left(\mathrm{H}_{2} \mathrm{O}\right)_{2}\right] 2 \mathrm{H}_{2} \mathrm{O} \quad$ (1), $\left[\mathrm{Mn}(\mathrm{hfac})_{2}(\mathrm{pym})\left(\mathrm{H}_{2} \mathrm{O}\right)\right] \quad(\mathbf{2}), \quad\left[\mathrm{Mn}(\mathrm{hfac})_{2}(\mathrm{pydz})_{2}\right] \quad$ (3) and $\left[\mathrm{Mn}(\mathrm{hfac})_{2}(\mathrm{mpydz})_{2}\right](\mathbf{4})($ pyz $=$ pyrazine, $\mathrm{pym}=$ 


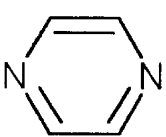

pyz

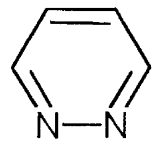

pydz

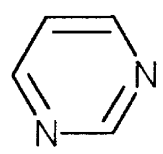

pym

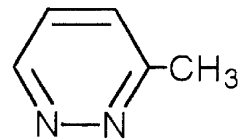

mpydz
Scheme 1 .

pyrimidine, pydz $=$ pyridazine, and $\mathrm{mpydz}=3$-methyl pyridazine) (Scheme 1). Here, we reported on the synthesis, X-ray crystal structure and cryomagnetic properties.

\section{EXPERIMENTAL}

\subsection{Preparation of compounds}

Bis(1,1,1,5,5,5-hexafluoropentane-2,4-dionate)manganese(II) dihydrate, $\mathrm{Mn}(\mathrm{hfac})_{2} \cdot 2 \mathrm{H}_{2} \mathrm{O}$, was prepared from the metal acetate by the literature procedures [10]. Pyrazine (pyz), pyrimidine (pym), pyridazine (pydz) and 3-methylpyridazine (mpydz) were purchased from a commercial source (Aldrich Chemical Co.) and used without further purification.

$\left[\mathrm{Mn}_{2}(\mathrm{hfac})_{4}(\mu-\right.$ pyz $\left.)\left(\mathrm{H}_{2} \mathrm{O}\right)_{2}\right] 2 \mathrm{H}_{2} \mathrm{O} \quad(\mathbf{1}), \quad\left[\mathrm{Mn}(\mathrm{hfac})_{2}\right.$ (pym) $\left.\left(\mathrm{H}_{2} \mathrm{O}\right)\right] \quad$ (2), $\quad\left[\mathrm{Mn}(\mathrm{hfac})_{2}(\mathrm{pydz})_{2}\right] \quad$ (3) and $\left[\mathrm{Mn}(\mathrm{hfac})_{2}(\mathrm{mpydz})_{2}\right]$ (4) were synthesized by mixing the absolute ethanol solutions of an equimolar quantity of the complex $\mathrm{Mn}(\mathrm{hfac})_{2} 2 \mathrm{H}_{2} \mathrm{O}$ and the diazines. The solutions were allowed to stand for a few days, orange-yellow crystals of $\mathbf{1}$ ( $75 \%$ yield), light-yellow crystals of $\mathbf{2}$ ( $85 \%$ yield), $\mathbf{3}$ (75\% yield) and $\mathbf{4}(80 \%$ yield) were filtered off, air dried and characterized initially by elemental analysis and then by single-crystal X-ray diffractional analysis. (Found: C, 26.5; H, 1.4; N, 2.7. Calc. for $\mathrm{C}_{24} \mathrm{H}_{16} \mathrm{~F}_{24} \mathrm{~N}_{2} \mathrm{Mn}_{2} \mathrm{O}_{12}$ (1): C, 2.64; $\mathrm{H}, 1.5$; N, 2.6\%. IR (KBr disc): 1650 vs, $1572 \mathrm{~m}, 1530$ m, $1502 \mathrm{~s}, 1250$ vs, $1200 \mathrm{~s}, 1152$ vs, $801 \mathrm{~m}, 670 \mathrm{~s}$, $600 \mathrm{~m} \mathrm{~cm}^{-1}$ Found: C, 29.5; H, 1.4; N, 4.9. Calc. for $\mathrm{C}_{14} \mathrm{H}_{8} \mathrm{~F}_{12} \mathrm{~N}_{2} \mathrm{MnO}_{5}$ (2): C, 29.6; H, 1.4, N, 4.9\%. IR (KBr disc): 1648 vs, $1594 \mathrm{~m}, 1561 \mathrm{~m}, 1535 \mathrm{~s}, 1491 \mathrm{~s}$, 1254 vs, 1209 vs, 1147 vs, 1079 m, 804 s, 715 m, 666 s, $587 \mathrm{~m} \mathrm{~cm}^{-1}$. Found: C, 34.2; H, 1.7; N, 8.9. Calc. for $\mathrm{C}_{18} \mathrm{H}_{10} \mathrm{~F}_{12} \mathrm{~N}_{4} \mathrm{MnO}_{4}(3)$ : C, 34.3; H, 1.6; N, 8.9\%. IR (KBr disc): 1652 vs, 1589 m, 1529 m, 1502 vs, 1450 m, 1423 m, 1259 vs, 1224 vs, 1199 vs, 1143 vs, 1090 m, $1068 \mathrm{~m}, 972 \mathrm{~s}, 796 \mathrm{~s}, 765 \mathrm{~m}, 605 \mathrm{vs}, 586 \mathrm{~m} \mathrm{~cm}^{-1}$. Found: $\mathrm{C}, \quad 36.3 ; \mathrm{H}, 2.2 ; \mathrm{N}, \quad 8.5$. Calc. for $\mathrm{C}_{20} \mathrm{H}_{14} \mathrm{~F}_{12} \mathrm{~N}_{4} \mathrm{MnO}_{4}$ (4): C, 36.5; H, 2.1; N, 8.5\%. IR
(KBr disc): 1648 vs, $1591 \mathrm{~m}, 1555$ s, 1526 s, 1459 vs, 1449 s, 1253 vs, 1216 s, 1197 s, 1147 vs, 1095 m, 821 m, $794 \mathrm{~s}, 663 \mathrm{~s}, 581 \mathrm{~m} \mathrm{~cm}^{-1}$.

\section{Physical measurements}

IR spectra were recorded on a Bio-Rad FTS40FTIR spectrophotometer as $\mathrm{KBr}$ pellets in the 4000 $400 \mathrm{~cm}^{-1}$ region. X-band EPR spectra at $25^{\circ} \mathrm{C}$ for the complexes in powder were recorded on a Bruker ESC106 spectrometer. Temperature dependence of magnetic susceptibilities of the polycrystalline samples were measured between 4 and $300 \mathrm{~K}$ at field $1 \mathrm{~T}$, using a Quantum Design Model MPMS computer-controlled SQUID magnetometer. Corrections for the diamagnetism of the complexes were estimated from Pascal's constants [11].

\section{Crystal structure determination}

Crystallographic data for complexes 1-4 were collected on an Enraf-Nonius CAD-4 diffractometer with graphite-monochromatized $\mathrm{Mo}-\mathrm{K}_{\alpha}$ radiation $(\lambda=0.7107 \AA)$ at $25^{\circ} \mathrm{C}$. Crystallographic parameters and pertinent refinement results are summarized in Tables 1 and 2. The structures were solved by the heavy-atom method using a Patterson map and refined by a full-matrix least-squares method based on $F$, using the NRCVAX software package [12]; the function minimized was $\sum w\left(\left|F_{\mathrm{o}}\right|-\left|F_{\mathrm{c}}\right|\right)^{2}$ with $w=1 / \sigma^{2}\left(F_{\mathrm{o}}\right)$ and unit weights were used. All nonhydrogen atoms were readily located and refined with anisotropic thermal parameters.

\section{RESULTS AND DISCUSSION}

\subsection{Crystal structures of complexes 1-4}

Perspective views with the atomic numbering of complexes 1, 2, 3, and $\mathbf{4}$ are shown in Figs 1-4, respectively. The selected bond distances and angles relevant to manganese coordination spheres are given in Tables 3-6.

Complex 1 has a centrosymmetric dinuclear structure and two adjacent manganese atoms, 5.968(4) $\AA$ apart, are linked by a pyz bridging ligand. This intermetallic separation is expected for a weak intramolecular antiferromagnetic exchange interaction between two $\mathrm{Mn}(\mathrm{II})$ atoms. The geometry about each manganese atom is distorted octahedral with $\mathrm{NO}_{5}$ coordination sphere. The axial positions are filled with the nitrogen atom of the bridging pyz ligand and the oxygen atom $[\mathrm{O}(5)]$ of the water molecule, while the four equatorial positions are occupied by four oxygens $[\mathrm{O}(4), \mathrm{O}(2), \mathrm{O}(3), \mathrm{O}(4)]$ from the bidentate hfac ligands. It is notable that $F(10), F(11)$ and $F(12)$ of the $\mathrm{CF}_{3}$ group of the hfac ligand are rotationally disordered about the $\mathrm{C}(11)-\mathrm{C}(12)$ bond. 
Table 1. Crystallographic data for complexes 1-2

\begin{tabular}{|c|c|c|}
\hline & 1 & 2 \\
\hline Formula & $\mathrm{C}_{24} \mathrm{H}_{16} \mathrm{~F}_{24} \mathrm{~N}_{2} \mathrm{Mn}_{2} \mathrm{O}_{12}$ & $\mathrm{C}_{14} \mathrm{H}_{8} \mathrm{~F}_{12} \mathrm{~N}_{2} \mathrm{Mn}_{2} \mathrm{O}$ \\
\hline Formula weight & 1090.22 & 567.14 \\
\hline Space group & Monoclinic, $P 2_{1} / \mathrm{c}$ & Triclinic, $P \overline{\mathrm{I}}$ \\
\hline$a(\AA)$ & $11.4342(19)$ & $8.8790(14)$ \\
\hline$b(\AA)$ & $24.937(6)$ & $10.8927(22)$ \\
\hline$c(\AA)$ & $7.007(3)$ & $11.759(3)$ \\
\hline$\alpha(\AA)$ & & $110.737(17)$ \\
\hline$\beta(\AA)$ & 104.17(3) & $90.351(15)$ \\
\hline$\gamma(\AA)$ & & $103.066(15)$ \\
\hline$V\left(\AA^{3}\right)$ & 1937.1(11) & $1031.4(3)$ \\
\hline$Z$ & 2 & 2 \\
\hline$D_{\text {calc }}\left(\mathrm{g} \mathrm{cm}^{-3}\right)$ & 1.869 & 1.826 \\
\hline$F(000)$ & 1072 & 558 \\
\hline Unit-cell detectionl $2 \theta$ range & $25 ;(14.70-24.10)$ & $25,(15.52-24.66)$ \\
\hline Scan type & $\theta / 2 \theta$ & $\theta / 2 \theta$ \\
\hline $2 \theta$ scan width $\left(^{\circ}\right)$ & $2(0.80+0.35 \tan \theta)$ & $2(0.60+0.35 \tan \theta)$ \\
\hline $2 \theta$ range $\left(^{\circ}\right)$ & 45.0 & 50 \\
\hline$\mu\left(\mathrm{Mo}-\mathrm{K}_{\alpha}\right)\left(\mathrm{cm}^{-1}\right)$ & 4.026 & 7.562 \\
\hline Crystal size (mm) & $0.05 \times 0.05 \times 0.50$ & $0.40 \times 0.40 \times 0.5$ \\
\hline Temperature (K) & 298 & 298 \\
\hline No. of uniqueness reflections & 2524 & 3638 \\
\hline No. of observed reflections $[I>2 \sigma(I)]$ & 1198 & 2945 \\
\hline$R, R_{w}{ }^{a}$ & $0.057 ; 0.051$ & $0.050 ; 0.051$ \\
\hline GoF & 1.77 & 1.58 \\
\hline$(\Delta / \sigma)_{\max }$ & 0.0241 & 0.0018 \\
\hline$(\Delta \rho)_{\min , \max }\left(\mathrm{e} \AA^{-3}\right)$ & $-0.380 ; 0.450$ & $-0.430 ; 0.510$ \\
\hline
\end{tabular}

${ }^{\mathrm{a}} R=\left[\Sigma \mid F_{\mathrm{o}}-F_{\mathrm{c}} / / F_{\mathrm{o}}\right], R_{w}=\Sigma w\left[\left|F_{\mathrm{o}}-F_{\mathrm{c}}\right|^{2} / \Sigma w\left(\left|F_{\mathrm{o}}\right|^{2}\right)\right]^{1 / 2}$.

Table 2. Crystallographic data for complexes 3-4

\begin{tabular}{lll}
\hline & $\mathbf{3}$ & $\mathbf{4}$ \\
\hline Formula & $\mathrm{C}_{18} \mathrm{H}_{14} \mathrm{~F}_{12} \mathrm{~N}_{4} \mathrm{MnO}_{4}$ & $\mathrm{C}_{20} \mathrm{H}_{14} \mathrm{~F}_{12} \mathrm{~N}_{4} \mathrm{MnO}_{4}$ \\
Formula weight & 633.253 & 657.27 \\
Space group & Monoclinic, $P 2_{1} / \mathrm{c}$ & Monoclinic, $P 2_{1} / \mathrm{n}$ \\
$a(\AA)$ & $13.333(3)$ & $14.993(7)$ \\
$b(\AA)$ & $11.0580(13)$ & $8.575(3)$ \\
$c(\AA)$ & $17.510(3)$ & $21.101(4)$ \\
$\beta(\AA)$ & $111.882(16)$ & $92.89(3)$ \\
$V\left(\AA^{3}\right)$ & $2395.7(7)$ & $2709.4(17)$ \\
$Z$ & 4 & 4 \\
$D_{\text {calc }}\left(\mathrm{g} \mathrm{cm}^{-3}\right)$ & 1.745 & 1.611 \\
$F(000)$ & 1260 & 1308 \\
Unit-cell detection; $2 \theta$ range & $25,(18.64-30.00)$ & $25 ;(14.96-22.32)$ \\
Scan type & $\theta / 2 \theta$ & $\theta / 2 \theta$ \\
$2 \theta$ scan width $\left({ }^{\circ}\right)$ & $2(0.70+0.35 \tan \theta)$ & $2(0.80+0.35 \tan \theta)$ \\
$2 \theta$ range $\left({ }^{\circ}\right)$ & 50 & 45 \\
$\mu\left(\right.$ Mo-K $\left.{ }_{\alpha}\right)\left(\mathrm{cm}^{-1}\right)$ & 6.486 & 5.794 \\
Crystal size $(\mathrm{mm})$ & $0.20 \times 0.30 \times 0.50$ & $0.20 \times 0.20 \times 0.20$ \\
Temperature $(\mathrm{K})$ & 298 & 298 \\
No. of uniqueness reflections & 4214 & 3739 \\
No. of observed reflections $[I>2 \sigma(I)]$ & 2717 & 1812 \\
$R, R_{w}{ }^{a}$ & $0.064 ; 0.060$ & $0.065 ; 0.065$ \\
GoF & 1.33 & 2.37 \\
$(\Delta / \sigma)_{\text {max }}$ & 0.0714 & 0.0107 \\
$(\Delta \rho)_{\text {min,max }}\left(\mathrm{e} \AA^{-3}\right)$ & $-0.590 ; 0.690$ & $-0.390 ; 0.460$ \\
\hline
\end{tabular}

\footnotetext{
${ }^{\mathrm{a}} R=\left[\Sigma\left|F_{\mathrm{o}}-F_{\mathrm{c}}\right| / F_{\mathrm{o}}\right], R_{w}=\Sigma w\left[\left|F_{\mathrm{o}}-F_{\mathrm{c}}\right|^{2} / \Sigma w\left(\left|F_{\mathrm{o}}\right|^{2}\right)\right]^{1 / 2}$.
} 


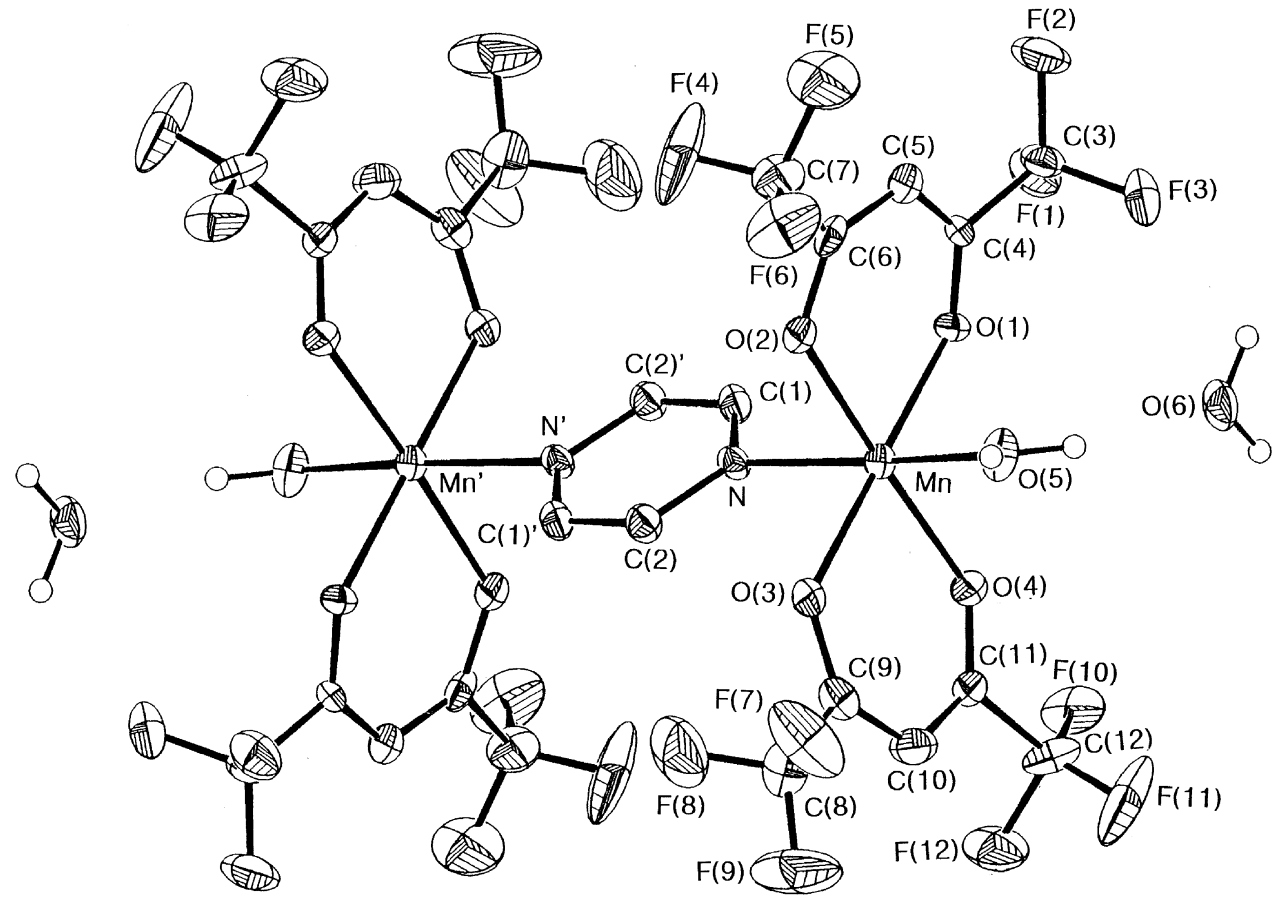

Fig. 1. Molecular structure of $\left[\mathrm{Mn}_{2}(\mathrm{hfac})_{4}(\mathrm{pyz})\left(\mathrm{H}_{2} \mathrm{O}\right)_{2} 2 \mathrm{H}_{2} \mathrm{O} 1\right.$ with the atomic numbering scheme $(30 \%$ probability thermal ellipsoids).

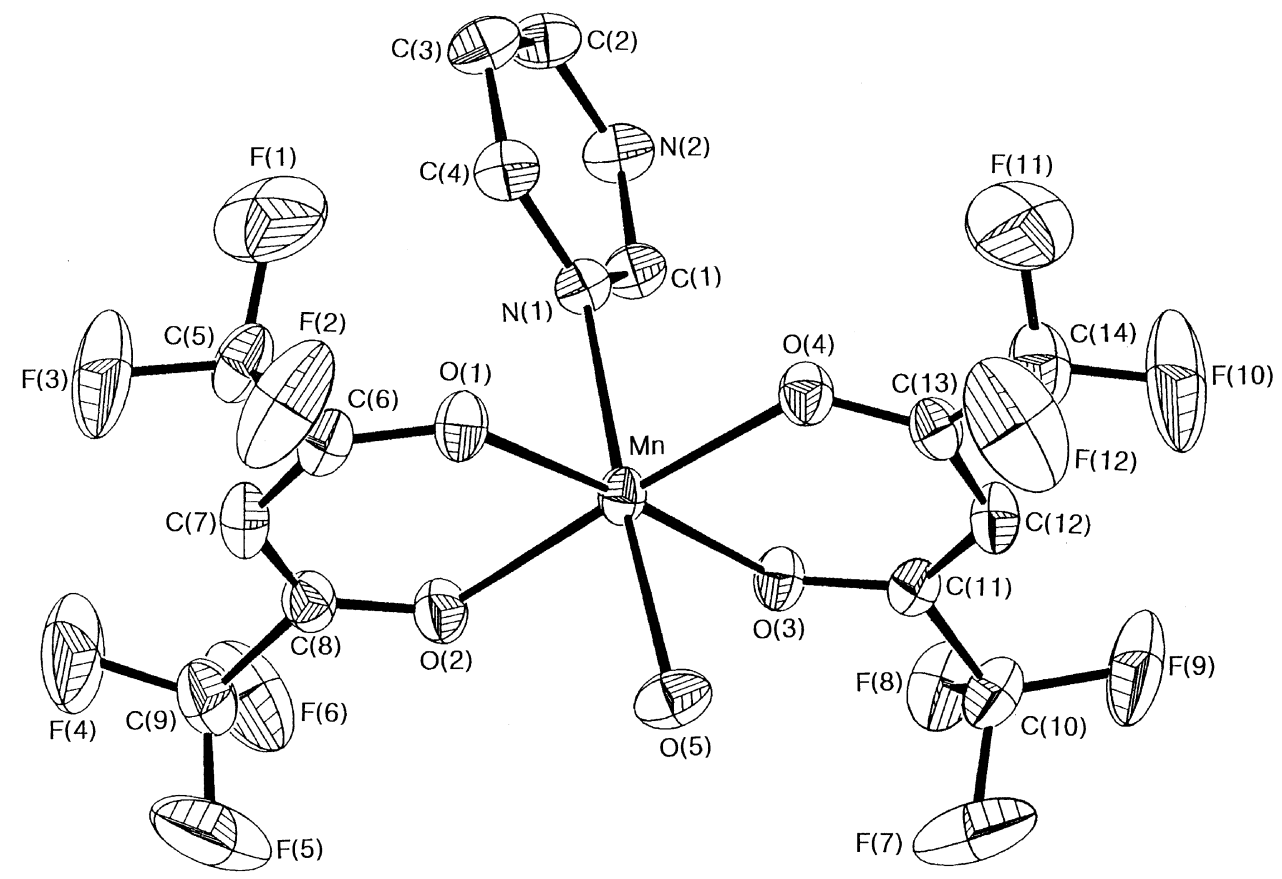

Fig. 2. Molecular structure of $\left[\mathrm{Mn}(\mathrm{hfac})_{2}(\mathrm{pym})\left(\mathrm{H}_{2} \mathrm{O}\right)\right] 2$ with the atomic numbering scheme $(30 \%$ probability thermal ellipsoids). 


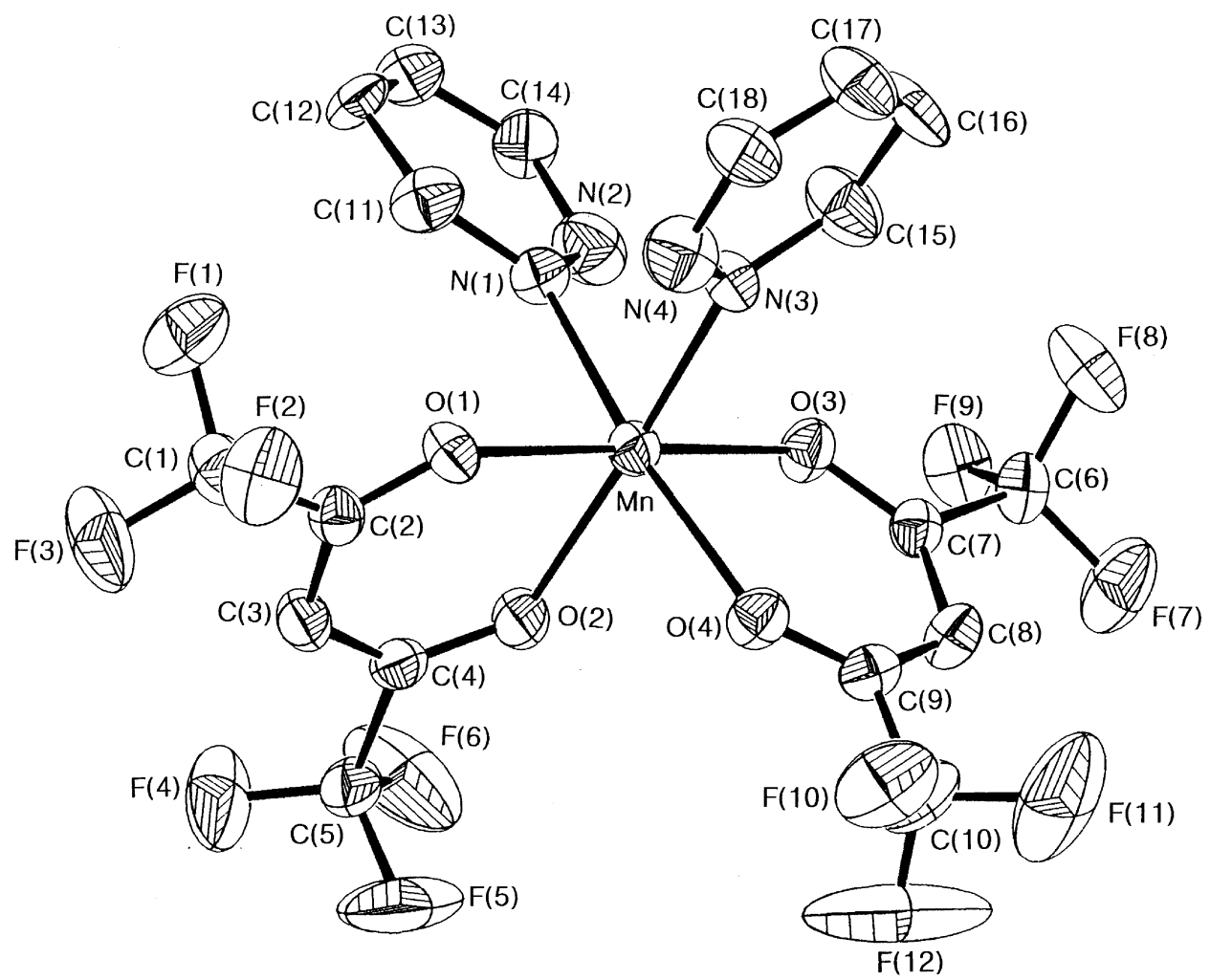

Fig. 3. Molecular structure of $\left[\mathrm{Mn}(\mathrm{hfac})_{2}(\mathrm{pydz})_{2}\right] 3$ with the atomic numbering scheme (30\% probability thermal ellipsoids).

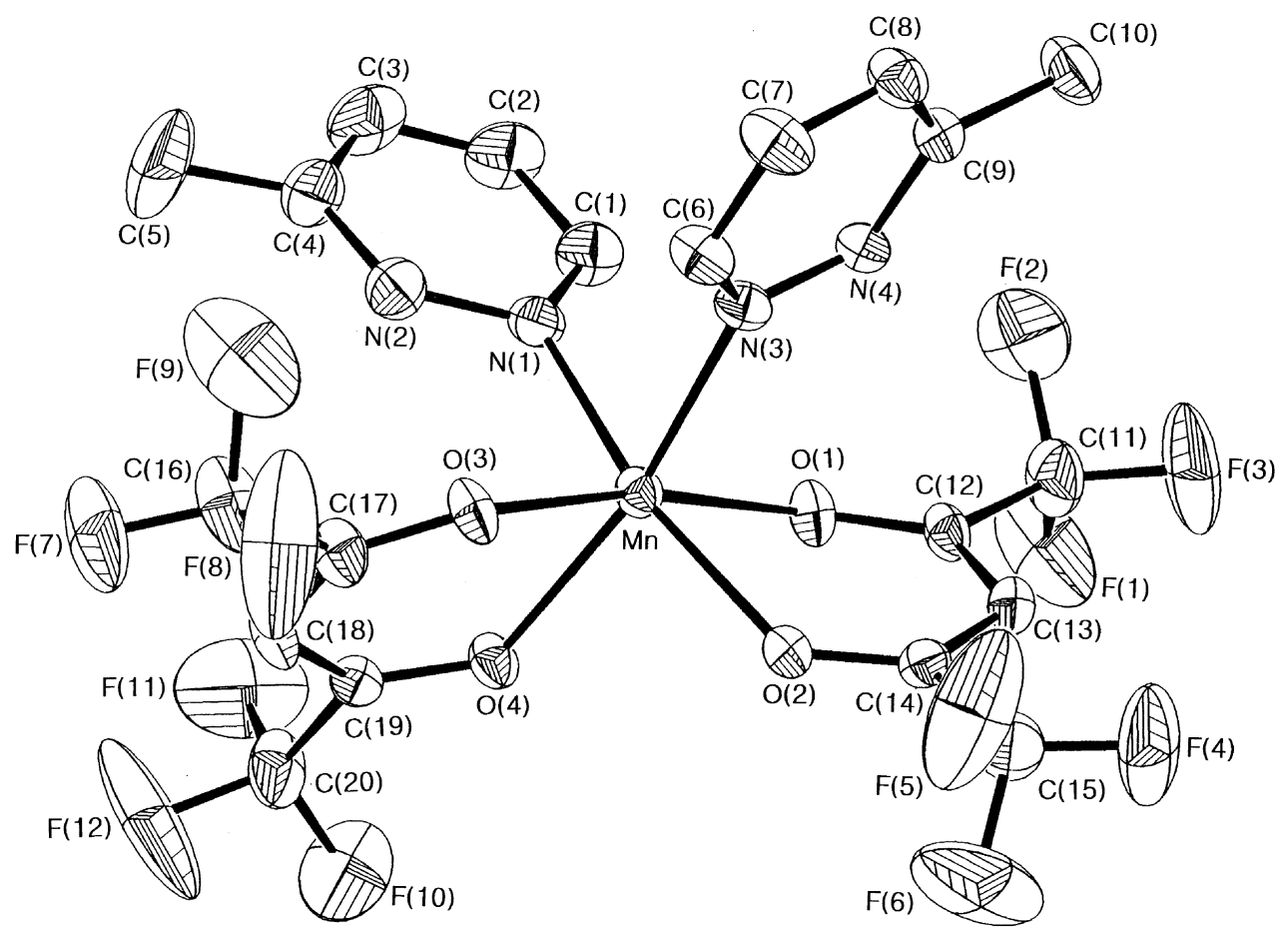

Fig. 4. Molecular structure of $\left[\mathrm{Mn}(\mathrm{hfac})_{2}(\mathrm{mpydz})_{2}\right] \mathbf{4}$ with the atomic numbering scheme (30\% probability thermal ellipsoids). 
Table 3. Selected bond distances $(\AA)$ and angles ( $\left.{ }^{\circ}\right)$ for $\mathbf{1}$

\begin{tabular}{llll}
\hline $\mathrm{Mn}-\mathrm{N}$ & $2.332(18)$ & $\mathrm{Mn}-\mathrm{O}(1)$ & $2.120(6)$ \\
$\mathrm{Mn}-\mathrm{O}(2)$ & $2.163(6)$ & $\mathrm{Mn}-\mathrm{O}(3)$ & $2.140(6)$ \\
$\mathrm{Mn}-\mathrm{O}(4)$ & $2.136(6)$ & $\mathrm{Mn}-\mathrm{O}(5)$ & $2.172(7)$ \\
$\mathrm{Mn} \cdots \mathrm{Mn}$ & $5.968(4)$ & & \\
& & & \\
$\mathrm{N}-\mathrm{Mn}-\mathrm{O}(5)$ & $172.6(3)$ & $\mathrm{O}(1)-\mathrm{Mn}-\mathrm{O}(3)$ & $178.7(3)$ \\
$\mathrm{O}(2)-\mathrm{Mn}-\mathrm{O}(4)$ & $175.1(3)$ & $\mathrm{O}(1)-\mathrm{Mn}-\mathrm{O}(2)$ & $84.24(24)$ \\
$\mathrm{O}(3)-\mathrm{Mn}-\mathrm{O}(4)$ & $84.46(25)$ & $\mathrm{O}(2)-\mathrm{Mn}-\mathrm{O}(3)$ & $95.2(3)$ \\
$\mathrm{O}(1)-\mathrm{Mn}-\mathrm{O}(4)$ & $95.94(24)$ & $\mathrm{O}(2)-\mathrm{Mn}-\mathrm{N}$ & $89.63(25)$ \\
$\mathrm{O}(3)-\mathrm{Mn}-\mathrm{N}$ & $89.71(25)$ & $\mathrm{C}(1)-\mathrm{N}-\mathrm{C}(2)$ & $115.9(8)$ \\
$\mathrm{Mn}-\mathrm{N}-\mathrm{C}(2)$ & $122.5(6)$ & & \\
\hline
\end{tabular}

Table 4. Selected bond distances $(\AA)$ and angles $\left(^{\circ}\right)$ for $\mathbf{2}$

\begin{tabular}{lrlr}
\hline $\mathrm{Mn}-\mathrm{N}(1)$ & $2.285(3)$ & $\mathrm{Mn}-\mathrm{O}(1)$ & $2.132(3)$ \\
$\mathrm{Mn}-\mathrm{O}(2)$ & $2.154(3)$ & $\mathrm{Mn}-\mathrm{O}(3)$ & $2.132(3)$ \\
$\mathrm{Mn}-\mathrm{O}(4)$ & $2.139(3)$ & $\mathrm{Mn}-\mathrm{O}(5)$ & $2.214(3)$ \\
& & & \\
$\mathrm{N}(1)-\mathrm{Mn}-\mathrm{O}(5)$ & $176.90(13)$ & $\mathrm{O}(1)-\mathrm{Mn}-\mathrm{O}(3)$ & $176.62(12)$ \\
$\mathrm{O}(2)-\mathrm{Mn}-\mathrm{O}(4)$ & $176.67(12)$ & $\mathrm{O}(1)-\mathrm{Mn}-\mathrm{O}(2)$ & $83.84(12)$ \\
$\mathrm{O}(3)-\mathrm{Mn}-\mathrm{O}(4)$ & $84.91(11)$ & $\mathrm{O}(1)-\mathrm{Mn}-\mathrm{N}(1)$ & $90.48(12)$ \\
$\mathrm{O}(2)-\mathrm{Mn}-\mathrm{O}(5)$ & $89.80(13)$ & $\mathrm{O}(3)-\mathrm{Mn}-\mathrm{O}(5)$ & $85.16(12)$ \\
$\mathrm{O}(4)-\mathrm{Mn}-\mathrm{N}(1)$ & $90.98(12)$ & $\mathrm{O}(1)-\mathrm{Mn}-\mathrm{O}(4)$ & $96.81(12)$ \\
$\mathrm{O}(2)-\mathrm{Mn}-\mathrm{O}(3)$ & $94.28(11)$ & $\mathrm{Mn}-\mathrm{N}(1)-\mathrm{C}(4)$ & $122.2(3)$ \\
$\mathrm{Mn}-\mathrm{N}(1)-\mathrm{C}(1)$ & $122.0(3)$ & &
\end{tabular}

Table 5. Selected bond distances $(\AA)$ and angles $\left({ }^{\circ}\right)$ for $\mathbf{3}$

\begin{tabular}{lclr}
\hline $\mathrm{Mn}-\mathrm{N}(1)$ & $2.270(5)$ & $\mathrm{Mn}-\mathrm{N}(3)$ & $2.258(5)$ \\
$\mathrm{Mn}-\mathrm{O}(1)$ & $2.130(4)$ & $\mathrm{Mn}-\mathrm{O}(2)$ & $2.188(4)$ \\
$\mathrm{Mn}-\mathrm{O}(3)$ & $2.118(4)$ & $\mathrm{Mn}-\mathrm{O}(4)$ & $2.195(4)$ \\
& & & \\
$\mathrm{N}(1)-\mathrm{Mn}-\mathrm{O}(4)$ & $168.74(17)$ & $\mathrm{N}(3)-\mathrm{Mn}-\mathrm{O}(2)$ & $171.78(17)$ \\
$\mathrm{O}(1)-\mathrm{Mn}-\mathrm{O}(3)$ & $175.1(17)$ & $\mathrm{O}(1)-\mathrm{Mn}-\mathrm{O}(2)$ & $24.36(15)$ \\
$\mathrm{O}(3)-\mathrm{Mn}-\mathrm{O}(4)$ & $82.28(15)$ & $\mathrm{O}(1)-\mathrm{Mn}-\mathrm{N}(1)$ & $91.73(17)$ \\
$\mathrm{O}(2)-\mathrm{Mn}-\mathrm{O}(4)$ & $87.40(17)$ & $\mathrm{O}(4)-\mathrm{Mn}-\mathrm{N}(3)$ & $91.04(13)$ \\
$\mathrm{N}(1)-\mathrm{Mn}-\mathrm{N}(3)$ & $90.72(19)$ & $\mathrm{O}(3)-\mathrm{Mn}-\mathrm{N}(3)$ & $94.06(18)$ \\
$\mathrm{Mn}-\mathrm{N}(1)-\mathrm{C}(11)$ & $122.1(4)$ & $\mathrm{Mn}-\mathrm{N}(1)-\mathrm{N}(2)$ & $121.8(4)$ \\
$\mathrm{Mn}-\mathrm{N}(3)-\mathrm{N}(4)$ & $122.0(4)$ & $\mathrm{Mn}-\mathrm{N}(3)-\mathrm{C}(15)$ & $122.5(4)$ \\
\hline
\end{tabular}

The average $\mathrm{Mn}-\mathrm{O}[2.115 \AA]$ bond distances of $\mathrm{Mn}-\mathrm{O}(1), \mathrm{Mn}-\mathrm{O}(2), \mathrm{Mn}-\mathrm{O}(3)$ and $\mathrm{Mn}-\mathrm{O}(4)$ are somewhat shorter than those of $\mathrm{Mn}-\mathrm{O}(5)$ [2.172(7) $\AA$ ] and $\mathrm{Mn}-\mathrm{N}$ [2.332(8) $\AA$ ] Table 2. The bond angles of $\mathrm{N}-\mathrm{Mn}-\mathrm{O}(1)\left[91.46(25)^{\circ}\right]$ and $\mathrm{N}-\mathrm{Mn}-\mathrm{O}(4)\left[95.2(3)^{\circ}\right]$ are larger than those of $\mathrm{N}-\mathrm{Mn}-\mathrm{O}(2)\left[89.63(25)^{\circ}\right]$ and $\mathrm{N}-\mathrm{Mn}-\mathrm{O}(3)\left[89.71(25)^{\circ}\right]$. Furthermore, the resultant bond angle of the axial $\mathrm{N}-\mathrm{Mn}-\mathrm{O}(5)\left[172.6(3)^{\circ}\right]$ deviated from $180^{\circ}$.

The structure of $\mathbf{2}$ is a mononuclear manganese(II) complex with a distorted octahedral geometry of $\mathrm{NO}_{5}$ coordination sphere. The manganese coordination sphere consists of two chelating hfac ligands, one monodentate pym ligand and one water molecule. The axial positions are occupied by nitrogen $[\mathrm{N}(1)]$ of the pym and oxygen $[\mathrm{O}(5)]$ of the water molecule, and the four equatorial positions are occupied by oxygen atoms from the bidentate hfac ligands that form a tetragonal plane. The in-plane equatorial average $\mathrm{Mn}-\mathrm{O}$ bond distances of $2.139 \AA$ are somewhat shorter than the axial $\mathrm{Mn}-\mathrm{O}(5)[2.214(3) \AA]$ and $\mathrm{Mn}-\mathrm{N}(5)$ [2.285(3) $\AA$ ] bond distances.

The crystal structure of $\mathbf{3}$ consists of the neutral $\left[\mathrm{Mn}(\mathrm{hfac})_{2}(\mathrm{pydz})_{2}\right]$ units. The complex has an approxi- 
Table 6. Selected bond distances $(\AA)$ and angles $\left({ }^{\circ}\right)$ for 4

\begin{tabular}{lrlr}
\hline $\mathrm{Mn}-\mathrm{N}(1)$ & $2.233(7)$ & $\mathrm{Mn}-\mathrm{N}(3)$ & $2.247(7)$ \\
$\mathrm{Mn}-\mathrm{O}(1)$ & $2.145(3)$ & $\mathrm{Mn}-\mathrm{O}(2)$ & $2.177(6)$ \\
$\mathrm{Mn}-\mathrm{O}(3)$ & $2.137(5)$ & $\mathrm{Mn}-\mathrm{O}(4)$ & $2.174(5)$ \\
& & & \\
$\mathrm{N}(1)-\mathrm{Mn}-\mathrm{O}(2)$ & $166.33(24)$ & $\mathrm{N}(3)-\mathrm{Mn}-\mathrm{O}(4)$ & $167.14(23)$ \\
$\mathrm{O}(1)-\mathrm{Mn}-\mathrm{O}(3)$ & $170.38(52)$ & $\mathrm{O}(1)-\mathrm{Mn}-\mathrm{O}(2)$ & $80.97(21)$ \\
$\mathrm{O}(3)-\mathrm{Mn}-\mathrm{O}(4)$ & $81.58(21)$ & $\mathrm{N}(1)-\mathrm{Mn}-\mathrm{O}(3)$ & $102.3(3)$ \\
$\mathrm{N}(3)-\mathrm{Mn}-\mathrm{O}(1)$ & $98.60(25)$ & $\mathrm{N}(1)-\mathrm{Mn}-\mathrm{O}(4)$ & $86.04(24)$ \\
$\mathrm{N}(3)-\mathrm{Mn}-\mathrm{N}(1)$ & $87.13(24)$ & $\mathrm{N}(3)-\mathrm{Mn}-\mathrm{O}(3)$ & $86.77(24)$ \\
$\mathrm{O}(1)-\mathrm{Mn}-\mathrm{O}(1)$ & $85.90(25)$ & $\mathrm{N}(1)-\mathrm{Mn}-\mathrm{N}(3)$ & $91.1(3)$ \\
$\mathrm{Mn}-\mathrm{N}(1)-\mathrm{N}(2)$ & $109.4(5)$ & $\mathrm{Mn}-\mathrm{N}(1)-\mathrm{C}(1)$ & $130.9(6)$ \\
$\mathrm{Mn}-\mathrm{N}(3)-\mathrm{N}(4)$ & $110.4(5)$ & $\mathrm{Mn}-\mathrm{N}(3)-\mathrm{C}(6)$ & $128.9(6)$ \\
\hline
\end{tabular}

mate $\mathrm{C}_{2}$ axis of symmetry. The coordination geometry of $\mathrm{Mn}$ belongs to the six-coordination type by virtue of two bidentate hfac and two pydz ligands, in which two pydz ligands are of cis arrangement. The three oxygens $[\mathrm{O}(2), \mathrm{O}(3), \mathrm{O}(4)]$ from the hfac and one nitrogen $[\mathrm{N}(1)]$ from the pydz ligand are approximately coplanar and the atoms of nitrogen $[\mathrm{N}(3)]$ of pydz and oxygen $[\mathrm{O}(2)]$ lie on an axial perpendicular to this plane. The bond distances of $\mathrm{Mn}-\mathrm{O}(2)$ [2.188(4) $\AA$ ] and $\mathrm{Mn}-\mathrm{O}(4)[2.195(4) \AA]$ show longer lengths than those of $\mathrm{Mn}-\mathrm{O}(1) \quad[2.130(4) \AA]$ and $\mathrm{Mn}-\mathrm{O}(3)$ $[2.118(4) \AA]$. Both of the $\mathrm{Mn}-\mathrm{O}(2)$ and $\mathrm{Mn}-\mathrm{O}(4)$ bonds are trans to the two pydz basic ligands, are lengthened compared with the others of $\mathrm{Mn}-\mathrm{O}(1)$ and $\mathrm{Mn}-\mathrm{O}(3)$ bonds due to a trans effect of the pydz ligands. The bond angles of $\mathrm{O}(1)-\mathrm{Mn}-\mathrm{O}(3)$ $\left[175.65(17)^{\circ}\right]$ are somewhat larger than those of $\mathrm{O}(2)$ $\mathrm{Mn}-\mathrm{N}(3) \quad\left[171.78(17)^{\circ}\right]$ and $\mathrm{O}(4)-\mathrm{Mn}-\mathrm{N}(1)$ $\left[168.74(17)^{\circ}\right]$. Furthermore, The bond angles of $\mathrm{Mn}-$ $\mathrm{N}(1)-\mathrm{N}(2) \quad\left[121.8(4)^{\circ}\right], \mathrm{Mn}-\mathrm{N}(1)-\mathrm{C}(11)\left[122.1(4)^{\circ}\right]$, $\mathrm{Mn}-\mathrm{N}(3)-\mathrm{N}(4) \quad\left[122.0(4)^{\circ}\right]$ and $\mathrm{Mn}-\mathrm{N}(3)-\mathrm{C}(15)$ $\left[122.5(4)^{\circ}\right]$ are similar and normal [13].

The crystal structure of $\mathbf{4}$ is also a mononuclear manganese(II) complex. The coordination geometry of $\mathrm{Mn}$ also belongs to the $\mathrm{N}_{2} \mathrm{O}_{4}$ distorted octahedral type, being similar to that of $\mathrm{Mn}$ in complex 3. The two pydz molecules are coordinated by the less hindered 1-nitrogen atoms $[\mathrm{N}(1)$ and $\mathrm{N}(3)]$. $\mathrm{Mn}-\mathrm{O}(2)$ [2.177(6) $\AA$ ] and $\mathrm{Mn}-\mathrm{O}(4)$ [2.174(5) $\mathrm{B}]$ bonds show longer lengths than $\mathrm{Mn}-\mathrm{O}(4)$ [2.145(5) $\AA$ ] and $\mathrm{Mn}$ $\mathrm{O}(3)[2.137(5) \AA]$ as well as in complex 3, these elongations are also due to a trans effect of the mpydz ligands. The bond angles of $\mathrm{Mn}-\mathrm{N}(1)-\mathrm{N}(2)\left[109.4(5)^{\circ}\right]$ and $\mathrm{Mn}-\mathrm{N}(3)-\mathrm{N}(4)\left[110.4(5)^{\circ}\right]$ are smaller than those of $\mathrm{Mn}-\mathrm{N}(1)-\mathrm{C}(1)\left[130.9(6)^{\circ}\right]$ and $\mathrm{Mn}-\mathrm{N}(3)-\mathrm{C}(6)$ $\left[128.9(6)^{\circ}\right]$. These different angles are probably due to the substantial steric interactions between the methyl groups of mpydz and the trifluoromethyl groups of hfac ligands. The resultant bond angles of $\mathrm{O}(2)-\mathrm{Mn}-$ $\mathrm{N}(1)$ and $\mathrm{O}(4)-\mathrm{Mn}-\mathrm{N}(3)$ are $166.33(24)^{\circ}$ and $167.14(23)^{\circ}$, respectively. Comparison of the $\mathrm{Mn}-$ $\mathrm{N}(1)$ and $\mathrm{Mn}-\mathrm{N}(3)$ bond distances for 4 and 3 give 2.233(7) vs. 2.270(7) $\AA$ and 2.247(7) vs. 2.258(5) $\AA$.
This may result from the rather higher basicity of the mpydz than the pydz ligand.

\section{EPR spectra and cryomagnetic properties}

The powder X-band EPR spectra $(9.80 \mathrm{GHz})$ at $300 \mathrm{~K}$ of complexes $\mathbf{1}$ and $\mathbf{2}$ display ca 0.062 and $0.095 \mathrm{~T}$, respectively, symmetric broad resonance absorptions with the same $g$ value of 2.02 . Whereas, at $300 \mathrm{~K}$, the EPR spectra, without discernible hyperfine structure of ${ }^{55} \mathrm{Mn}$, for $\mathbf{3}$ and $\mathbf{4}$ are observed with resonances at $g$ : $5.4(\mathrm{w}), 3.18(\mathrm{w}), 2.03(\mathrm{~s})$ and $1.42(\mathrm{w})$ for 3; $6.7(\mathrm{w}), 2.70(\mathrm{w}), 1.96(\mathrm{~s})$ and $1.47(\mathrm{w})$ for 4. These data thus indicate that, in complexes $\mathbf{3}$ and $\mathbf{4}$, and even in complexes $\mathbf{1}$ and $\mathbf{2}$, there exist weak magnetic interactions or zero-field splitting interactions $(D)$. Although the low temperature EPR spectrum for the present complexes has not been determined, in our case however, for octahedral high-spin $\mathrm{Mn}(\mathrm{II})$, due to its smaller Jahn-Teller effect, in general, the values of $D$ for the present species are of the order of $10^{-2} \mathrm{~cm}^{-1}$ $[14,15]$.

The cryomagnetic behavior of complex 1 represented by the plots of molar magnetic susceptibility, $\chi_{m}$ and $\chi_{m} T$ vs. $T$ is depicted in Fig. 5. At $300 \mathrm{~K}$, $\chi_{m} T=8.15 \mathrm{~cm}^{3} \mathrm{Kmol}^{-1}$, a value somewhat smaller than expected for two uncoupled manganese(II) ions; $\chi_{m} T$ slowly decreases upon cooling and reaches a value of $7.34 \mathrm{~cm}^{3} \mathrm{Kmol}^{-1}$ at $4 \mathrm{~K}$. Such a behavior is characteristic of a weak antiferromagnetic interaction between two high-spin manganese(II) ions. We have attempted to reproduce theoretically the experimental magnetic data of dinuclear complex 1 by use of the temperature-dependent magnetic susceptibility expression eq. (1) [16],

$$
\chi_{m}=\left(2 N g^{2} \mu_{B} / k T\right)(A / B),
$$

based on the isotropic Heisenberg model $\left(H=-2 J S_{1} S_{2}\right)$, without intermolecular interaction and the $\mathrm{Mn}(\mathrm{II})$ single-ion zero-field considerations, coupling for $S_{1}=S_{2}=5 / 2$, where $A=x^{28}+5 x^{24}+$ $14 x^{18}+30 x^{10}+55, B=x^{30}+3 x^{28}+5 x^{24}+7 x^{18}+9 x^{10}+$ 


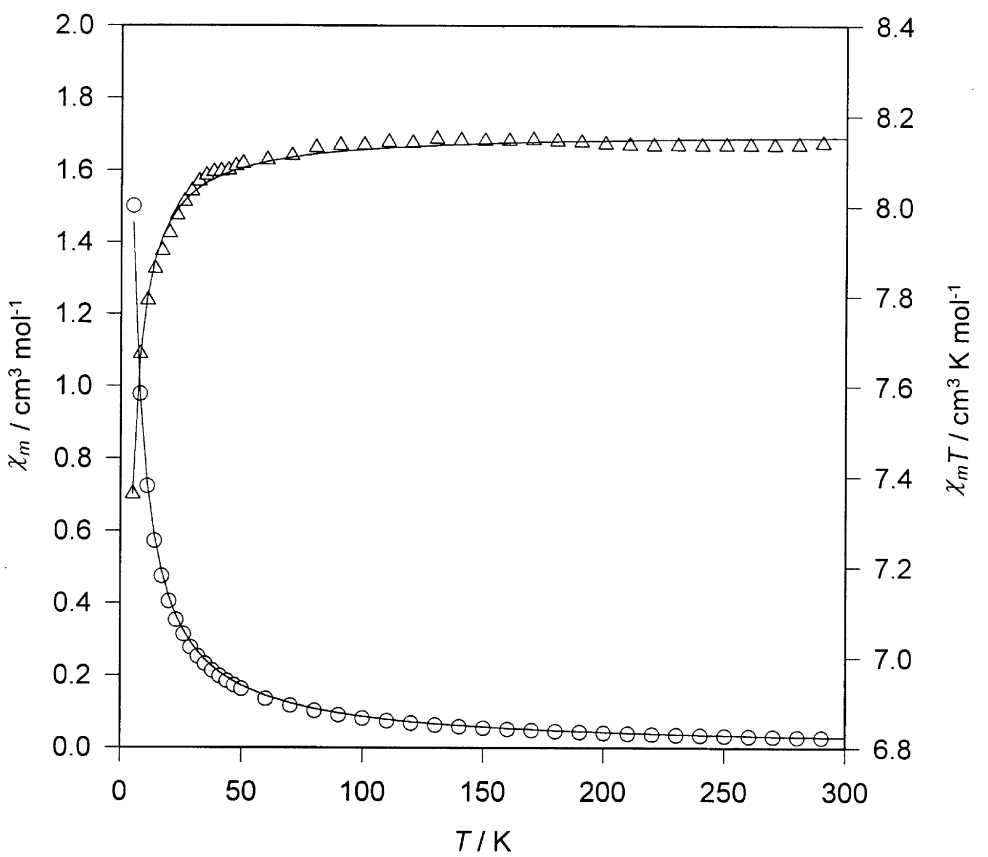

Fig. 5. Plots of $\chi_{m}(O)$ and $\chi_{m} T(\triangle)$ vs. $T$ for $\left[\mathrm{Mn}_{2}(\mathrm{hfac})_{4}(\mathrm{pyz})\left(\mathrm{H}_{2} \mathrm{O}\right)_{2}\right] 2 \mathrm{H}_{2} \mathrm{O} 1$. The solid line is the fit provided by equation (1) (see text).

11 and $x=\exp (-J / k T)$; the other symbols have their usual meanings. The temperature-independent paramagnetics for $\mathrm{Mn}(\mathrm{II})$ are assumed to be zero. Values of $-0.47 \mathrm{~cm}^{-1}$ and 2.02 were obtained for $J$ and $g$, respectively. The best data fits, as shown in Fig. 5 (the solid lines), display that a satisfactory match to the experimental data is achieved. Consequently, the weak antiferromagnetic coupling $J$ for $\mathbf{1}$ most likely accounts for the longer metal-metal separation $(5.97 \AA)$ through the bridged pyrazine ligand.

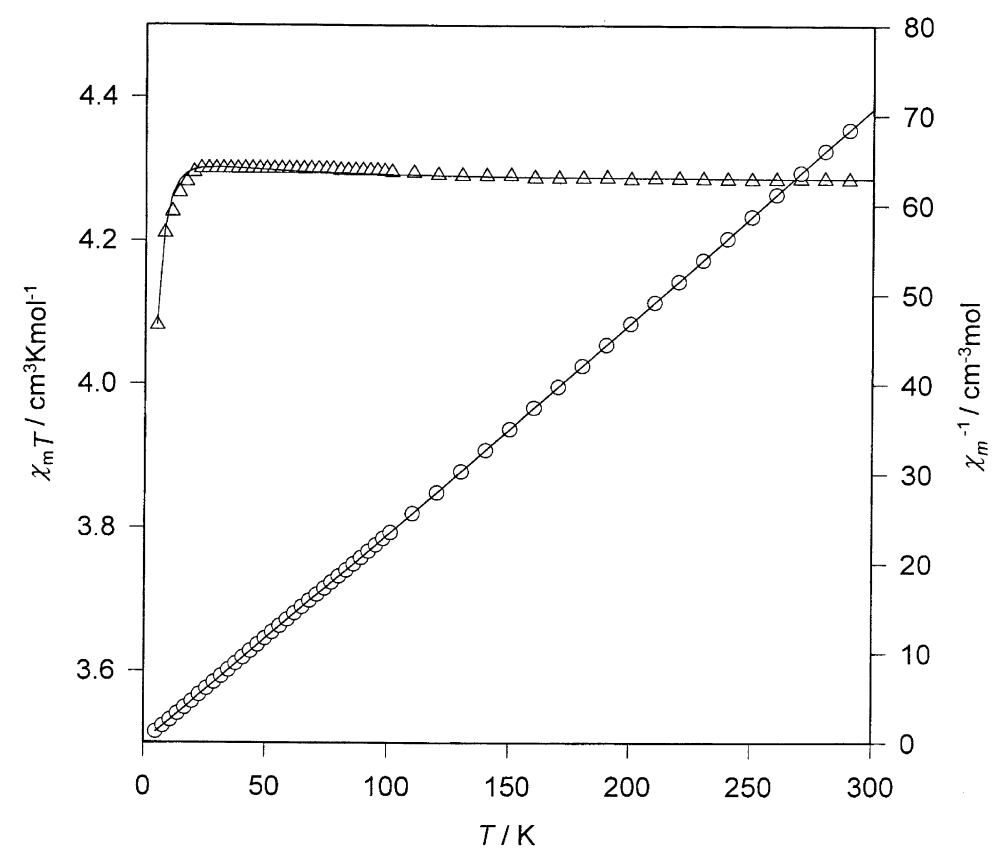

Fig. 6. Plots of $\chi_{m}^{-1}(\bigcirc)$ and $\chi_{m} T(\triangle) v s . T$ for $\left[\mathrm{Mn}(\mathrm{hfac})_{2}(\mathrm{pydz})_{2}\right]$ 3. The solid line is the fit provided by equation (2) (see text). 
Magnetic susceptibility measurements for mononuclear complexes 2-4 were made on powder samples in the temperature range $4-300 \mathrm{~K}$. The values of $\chi_{m} T$ at $300 \mathrm{~K}$ are in the range $4.30-4.38 \mathrm{~cm}^{3} \mathrm{Kmol}^{-1}$ and are close to the spin-only value $\left(4.377 \mathrm{~cm}^{3} \mathrm{Kmol}^{-1}\right)$ of the high-spin $\mathrm{Mn}(\mathrm{II})$ ion. The $\chi_{m}^{-1}$ and $\chi_{m} T$ vs. $T$ plots for 2-4 show a typical behavior for the paramagnetic species which obey the Curie-Weiss law. The presentative plots of $\chi_{m}^{-1}$ and $\chi_{m} T v s$. $T$ for complex $\mathbf{3}$, as shown in Fig. 6 and the $\chi_{m} T$ values decrease as the temperature below $c a 15 \mathrm{~K}$. The drop in $\chi_{m} T$ below $15 \mathrm{~K}$ may be the result of an intermolecular antiferromagnetic interaction or zero-field splitting $(D)$ of the spin multiples [14-16]. Since the inverse susceptibility plots are linear as a function of temperature for complexes 2-4, the Curie-Weiss law eq. (2), without zerofield splitting consideration, was used in the preliminary fits of the data.

$$
\chi_{m}=N g^{2} \mu_{B} S(S+1) / 3 k(T-\theta)
$$

The solid lines in Fig. 6 for complex 3 are the fit of the data to the susceptibility eq. (2), using the parameters $g=2.01$, and $\theta=-1.05 \mathrm{~K}$. Similarly, the cryomagnetic properties of $\mathbf{2}$ and $\mathbf{4}$ are also well reproduced by eq. (2). The best-fitting magnetic parameters are $g=2.0$ with $\theta=-1.25 \mathrm{~K}$ for 2 and $g=2.02$ with $\theta=-1.45 \mathrm{~K}$ for 4 . The molecular field exchange constant, $J^{\prime}$, may be calculated from $\theta=z J^{\prime} S(S+1) / 3 k$ [17] and $z$ is the number of the nearest neighbours. The values obtained for $z J^{\prime}$ in this manner are -0.25 , -0.30 and $-0.34 \mathrm{~cm}^{-1}$ for $\mathbf{2}, 3$ and 4 , respectively. These $z J^{\prime}$ values indicate the existence of very weak intermolecular antiferromagnetic interactions in complexes 2-4.

Acknowledgements-This work was supported by the National Science Council of Taiwan through Grant No. NSC87-2113-M-032-002.

\section{REFERENCES}

1. (a) Pecoraro, V. L. (ed.), Managnese Redox Enzymes. VCH, New York, 1992, p. 29-45; (b) Dismukes, G. C., Chem. Rev., 1996, 96, 29092926.

2. Dismukes, G. C., Photochem. Photobiol., 1986, 42, 187.

3. Barynin, V. V., Vagin, A. A., Melik-Adamyan, V. R., Grebenko, A. I., Khangulov, S. V., Popov, A. N., Andrianova, M. E. and Vainstein, B. K., Dolk. Akad. Nauk. S.S.S.R., 1986, 228, 877.

4. George, G., Prione, R. C. and Cramer, S. P., Science, 1989, 243, 789.

5. (a) Laeson, E. J. and Pecoraro, V. L., J. Am. Chem. Soc., 1991, 113, 7809; (b) Laeson, E. J.,
Riggs, P. J., Penner-Hahn, J. E. and Pecoraro, V. L., J. Chem. Soc., Chem. Commun., 1992, 102; (c) Nagata, T., Ikawa, Y. and Maruyama, K., J. Chem. Soc., Chem. Commun., 1994, 471; (d) Naruta, N. and Sasayama, M., J. Chem. Soc., Chem. Commun., 1994, 2667; (e) Casey, M. T., McCann, M., Dervereux, M., Curran, M., Cardin, C., Convery, M., Quillet, V. and Harding, C., J. Chem. Soc., Chem. Commun., 1994, 2643; (f) Pessiki, P. J. and Dismukes, G. C., J. Am. Chem. Soc., 1994, 116, 898; (g) Devereux, M., Mccann, M., Casey, M. T., Curran, M., Ferguson, G., Cardin, C., Convery, M. and Quillet, V., J. Chem. Soc., Dalton Trans., 1995, 771.

6. (a) Higuchi, C., Sakiyama, H., Okawa, H. and Fenton, D. E., J. Chem. Soc., Dalton Trans., 1995, 5015; (b) Sakiyama, H., Okawa, H. and Isobe, R., J. Chem. Soc., Chem. Commun., 1993, 882; (c) Higuchi, C., Sakiyama, H., Okawa, H., Isobe, R. and Fenton, D. E., J. Chem. Soc., Dalton Trans., 1994, 1097; (d) Aono, T., Wada, H., Yonemura, M., Ohba, M., Okawa, H. and Fenton, D. E., $J$. Chem. Soc., Dalton Trans., 1997, 1527.

7. Hong, D. M., Wei, H. H., Gan, L. L., Lee, G. H. and Wang, Y., Polyhedron, 1996, 15, 2335.

8. Hong, D. M., Wei, H. H. and Chang, K. H., J. Chin. Chem. Soc., (Taipei) In press.

9. (a) Thompson, L. K., Tandon, S. S. and Manuel, M. E., Inorg. Chem., 1995, 34, 2356; (b) Otieno, T., Rettig, S. J., Thompson, R. C. and Trotter, J., Inorg. Chem., 1995, 34, 1718; (c) Carlussi, L., Ciani, G., Moret, M. and Sironi, A., J. Chem. Soc., Dalton Trans., 1994, 2397; (d) Masciocchi, N., Cairati, P., Carlucci, L., Ciani, G., Mezza, G. and Sironi, A., J. Chem. Soc., Dalton Trans., 1996, 2117.

10. Charles, R. G., Inorg. Syn., 1960, 6, 164.

11. Carlin, R. L., Magnetochemistry. Springer Verlag, Berlin Heidelberg, 1986, p. 3.

12. Gate, E. J., Le Page, Y., Cherland, J. P., Lee, F. L. and White, P. S., J. Appl. Crystallogr., 1989, 22, 384.

13. Kogane, T., Kobayashi, K., Ishii, M., Hirota, R. and Nakahara, A. A., J. Chem. Soc., Dalton Trans., 1994, 13.

14. (a) Ménage, S., Vitols, S. E., Bergerat, P., Codjovi, E., Kahn, O., Girerd, J. J., Guillot, M., Solans, X. and Calvet, T., Inorg. Chem., 1991, 30, 2666; (b) Mabad, B., Cassoux, P., Tuchgues, J. P. and Hendrickson, D. N., Inorg. Chem., 1986, 25, 1420 .

15. (a) Mathur, P., Crowder, M. and Dismukes, G. C., J. Am. Chem. Soc., 1989, 109, 5227; (b) Pessik, P. J., Khangulov, S. V., Ho, D. M. and Dismukes, G. C., J. Am. Chem. Soc., 1994, 116, 891.

16. (a) Ginsberg, P. and Lines, M. E., Inorg. Chem., 1972, 11, 2289; (b) O'Connor, C. J., Prog. Inorg. Chem., 1982, 29, 203.

17. Kahn, O., Molecular Magnetism. VCH, New York, 1993, p. 26. 